\title{
Perkembangan Sosial-emosional Siswa Broken Home di Usia Sekolah Dasar \\ (Studi Kasus: Analisis Siswa Kelas II Mi Roudlotus Saidiyyah Semarang)
}

\author{
Muhammad Fikri Abdun Nasir \\ UIN Sunan Kalijaga, Yogyakarta, Indonesia \\ fikriman27@gmail.com \\ Ichsan \\ UIN Sunan Kalijaga, Yogyakarta, Indonesia \\ ichsandjalal@gmail.com
}

\begin{abstract}
Abstrak
Penelitian ini bertujuan untuk (1) mengetahui perkembangan sosialemosional siswa Broken home di MI Roudlotus Saidiyyah Semarang pada saat proses pembelajaran, (2) mengetahui perkembangan sosial-emosional siswa Broken home di MI Roudlotus Saidiyyah Semarang pada saat di luar kelas (bermain), (3) mengetahui upaya guru dalam mengembangkan sosial-emosional siswa. Penelitian ini menggunakan metode penelitian kualitatif dengan pendekatan studi kasus. Data diperoleh melalui wawancara dan observasi. Setelah data terkumpul kemudian melakukan reduksi data-penyajian data-dan menyimpulkan. Adapun hasil dari penelitian ini yakni, siswa Broken home mampu beriteraksi dan berkomunikasi dengan baik, mempunyai rasa percaya tinggi, menunjukkan sikap saling kasih sayang, berpartisipasi dalam kegiatan kerjasama, mudah bergaul, peka terhadap lingkungan. Anak tersebut dapat mencapai perkembangan sosial-emosial sesuai dengan teman sebayanya atas bimbingan khusus oleh guru yang berada dalam lingkungannya. dalam membimbing, guru selalu memberikan arahan, dorongan, dukungan, dan stimulus sehingga anak tersebut mampu merangsang dengan baik.
\end{abstract}

Kata kunci: Perkembangan, Sosial-Emosional, Anak Broken Home 


\begin{abstract}
Socio-emotional Development of Broken Home Students at Elementary School Age (Case Study: Analysis of Class II Student Mi Roudlotus Saidiyyah Semarang). This study aims to (1) determine the socio-emotional development of Broken home students at MI Roudlotus Saidiyyah Semarang during the learning process, (2) determine the socio-emotional development of Broken home students at MI Roudlotus Saidiyyah Semarang when outside of class (playing), (3) knowing the teacher's efforts in developing students' socioemotional. This study uses a qualitative research method with a case study approach. Data obtained through interviews and observations. After the data is collected then perform data reduction-data presentation-and conclude. The results of this study are, Broken home students are able to interact and communicate well, have high trust, show mutual affection, participate in cooperative activities, easy to get along with, sensitive to the environment. The child can achieve socioemotional development in accordance with his peers with special guidance by the teacher who is in his environment. In guiding, the teacher always provides direction, encouragement, support, and stimulus so that the child is able to stimulate well.
\end{abstract}

Keywords: Developmental, Socio-Emotional, Child Broken Home

\title{
A. Pendahuluan
}

Keluarga merupakan pusat pendidikan pertama yang dikenal oleh anak. Keluarga sebagai wadah dalam tumbuh dan berkembangnya anak dan orang tua menjadi pusat awal dan sangat menentukan dalam proses pembinaan, dan pembentukan kepribadian anak sejak dini. Melalui pengalaman dan sentuhan pendidikan yang diberikan orang tua, baik secara fisik maupun moral-spiritual, secara langsung akan di rangsang oleh anak dan tertanam dalam kepribadian anak tersebut.

Quintilianus, salah seorang tokoh dibidang pendidikan dan ilmu psikologi perkembangan mengemukakan bahwa, "kesan-kesan yang diperoleh anak ketika masih kecil akan tertanam secaramendalam dan menjadi milik abadi didalam 
jiwanya" (Imam Bawani, 1990:52). Lingkungan keluarga terutama orang tua dianggap berpengaruh dalam proses pengembangan kepribadian anak sehingga orang tua diharapkan mampu menciptakan lingkungan keluarga yang sesuai dengan keadaan anak. Selain itu orang tua hendaknya bersikap tegas dan bijak dalam memberi larangan dan berupaya merangsan anak menjadi seseorang yang percaya diri. Peran dan tugas orang tua menurut Ali, yakni sebagai berkut "Komunikasi Ibu dan Ayah dalam keluarga sangat menentukan pembentukan pribadi anak-anak di dalam maupun di luar rumah" (Ali, 1995:30).

Keluarga juga merupakan lingkungan sosial pertama bagi anak dan tempat anak dalam mendapatkan perlindungan, kasih sayang, serta rasa aman. Menurut Tabroni, dikatakan keluarga utuh apabila pasangan suami istri mempunyai tujuan membangun sebuah keluarga dengan visi dan misi yang akan dijalankan bersama sama. Keluarga utuh sangat berpeluang besar bagi anak untuk membangun kepercayaan terhadap kedua orang tuanya, yang merupakan unsur dalam membantu anak untuk memiliki dan mengembangkan diri. Pasangan suami istri yang tinggal terpisah karena alasan tertentu akan mengurangi makna sebagai keluarga yang utuh.

Anak yang memiliki orang tua utuh (Ayah dan Ibu) cenderung dinilai lebih baik daripada anak yang berasal dari keluarga yang telah bercerai atau keluarga tiri. Broken Home adalah suatu keadaan dimana orang tua sudah tidak harmonis, sering bertengkar dan menimbulkan keributan, sehingga tidak ada lagi rasa kasih sayang dan kepedulian terhadap anak, dan anak tidak lagi mendapatkan seseorang untuk dijadikan tauladan bagi mereka.

Dalam perkembangan psikologis peneliti membatasi pada aspek sosialemosional pada anak usia sekolah dasar. Perkembangan sosial siwa Sekolah Dasar anak dapat berkompetensi dengan teman sebaya, mempunyai sahabat, mandiri, dapat berbagi. Sedangkan dari segi emosi siswa Sekolah Dasar dapat mengekspresikan reaksi terhadap orang lain, dan dapat mengontrol emosi (Zusani, 2013). 
Perkembangan sosial-emosional merupakan dua perkembangan yang tidak dapat dipisahkan, karena keduanya saling berhubungan. Ketika siswa usia dasar mempunyai perkembangan sosial-emosional yang baik maka siswa tersebut akan mudah bergaul dan berinteraksi secara baik kepada semua orang maupun lingkungan belajar dan aktivitas lingkungan sosial.

Dalam dunia pendidikan, perkembangan sosial-emosional menempati kedudukan yang tak kalah penting selain perkembangan kogitif siswa, karena perkembangan sosial-emosional siswa sangat berpengaruh dilingkungan sekolah maupun lingkungan masyarakat. Perkembangan sosial-emosional siswa Sekolah Dasar sangat berpengaruh terhadap perilaku, pengendalian, penyesuaian dan aturan-aturan. Ketika siswa mampu mengkondisikan diri dengan lingkungan maka fungsi dari sosial emosionalnya akan semakin baik. Adapun perkembangan sosialemosional anak dipengaruhi oleh dua faktor, yaitu faktor keluarga dan lingkungan.

Perkembangan sosiaol-emosional merupakan proses perkembangan kemampuan anak dalam menyelesaikan diri terhadap dunia sosial yang lebih luas. Pada masa ini, anak menjadi lebih peka terhadap perasaannya sendiri dan juga orang lain. Siswa akan lebih baik mengatur ekspresi emosionalnya dalam situasi sosial dan mereka dapatmerespons tekanan emosional orang lain. Pada masa perkembangan sosial-emosional siswa, peran orang tua dan guru sangat berpengaruh terhadap terbentuknya perkembangan sosial-emosional yang baik.

Perkembangan sosial-emosional usia dasar perlu diperhatikan untuk mendapatkan perhatian khusus dari pihak orang tua maupun pihak sekolah karena perkembangan sosial-emosional merupakan pengarah bagi siswa untuk berkomunikasi dan berinteraksi secara baik kepada setiap kelompok sosial dan mampu menyesuaikan diri terhadap emosi yang dimiliki. Menurut Prasito, perkembangan sosial anak dapat dipengaruhi oleh beberapa faktor, diantaranya status sosial ekonomi keluarga, keutuhan keluarga, sikap dan kebiasaan orang tua, lingkungan, dan teman. 
Perke mbangan Sosial-emosional Sis wa ...

Perkembangan emosi anak akan sejalan dengan tahap-tahap perkembangan anak terutama pada masa Sekolah Dasar yeng perkembangannya akan semakin kompleks tergantung dengan pengalaman apa yang telah di dapatkannya. Perkembangan emosi anak juga akan berpengaruh terhadap mental anak sehingga perkembangan anak sangat perlu diperhatikan agar tidak ada pengaruh negatif yang akan berdampak pada mental anak.

\section{B. Metode}

Penelitian ini menggunakan penelitian kualitatif dengan pendekatan studi kasus. Studi kasus menurut Dedi Mulyana merupakan uraian dan penjelasan komprehensif mengenai berbagai aspek seorang individu, suatu kelompok, suatu organisasi (komunitas), suatu program, atau suatu situasi sosial.

Populasi dalam penelitian ini adalah guru MI Roudlotus Saidiyyah Semarang. Adapun teknik pengumpulan data pada penelitian ini adalah wawancara, observasi. Metode wawancara pada penelitian ini dilakukan dengan memberikan pertanyaan-pertanyaan yang relevan secara tatap muka, peneliti melakukan wawancara dengan Bude dan guru subjek. Metode observasi dilakukan dengan cara pengamatan dan pencatatan secara sistematis terhadap gejala yang tampak pada obyek penelitian. Selanjutnya data yang diperoleh di analisis dengan cara reduksi data, mengolah data, dan ditarik kesimpulan.

\section{Pembahasan}

\section{Perkembangan Sosial-emosional}

Sosial emosional terdiri dari dua kata yaitu sosial dan emosional. Menurut Plato secara potensial (fitrah) manusia dilahirkan sebagai makhluk sosial (zoon politicon). Syamsuddin Makmun (1996, p. 105) mengungkapkan bahwa "sosialisasi adalah proses belajar untuk menjadi makhluk sosial", sedangkan menurut Loree (1970: 86) "sosialisasi merupakan suatu proses dimana individu (terutama) anak melatih kepekaan dirinya terhadap rangsangan-rangsangan sosial terutama tekanan-tekanan dan tuntutan kehidupan (kelompoknya) serta belajar bergaul dengan bertingkah laku, seperti orang lain di dalam lingkungan sosialnya”. Hal ini 
senada dengan pendapat Hurlock (2004: 203) yang menjelaskan bahwa perkembangan sosial anak merupakan perolehan kemampuan berperilaku yang sesuai dengan tuntutan sosial.

Beaty dalam Susanto (2013: 136), menyatakan bahwa perkembangan sosial anak berkaitan dengan perilaku prososial dan bermain sosialnya. Aspek perilaku sosial meliputi: (1) Empati, yaitu menunjukkan perhatian kepada orang lain yang kesusahan atau menceritakan perasaan orang lain yang mengalami konflik. (2). Kemurahan hati, yaitu berbagi sesuatu dengan yang lain atau memberikan barang miliknya. (3). Kerja sama, yaitu bergantian menggunakan barang, melakukan sesuatu dengan gembira. (4). Kepedulian, yaitu membantu orang lain yang sedang membutuhkan bantuan (Susanto, 2013: 145). Jadi secara psikologis, pada tahap ini kemampuan anak baik secara interpersonal maupun personal satu sama lainnya saling mempengaruhi.

Sedangkan emosional yang terdiri dari kata awal yaitu emosi adalah perasaan yang ada dalam diri anak, dapat berupa perasaan senang atau tidak senang, perasaan baik atau buruk. Rachmawati (2013) emosi didefinisikan berbagai perasaan yang kuat, seperti perasaan benci, takut, marah, cinta, senang dan kesedihan. Macam-macam perasaan tersebut adalah gambar dari aspek emosional. Goleman (2015: 112) menyatakan bahwa emosi merujuk pada suatu perasaan atau pikiran-pikiran khasnya, suatu keadaan biologis dan psikologis serta serangkaian kecenderungan untuk bertindak.

Santrock dalam Nurmalitasari (2015) mendefinisikan emosi sebagai perasaan atau afeksi yang timbul ketika seseorang berada dalam suatu keadaan yang dianggap penting oleh individu tersebut. Emosi diwakilkan oleh perilaku yang mengekspresikan kenyamanan atau ketidaknyamanan terhadap keadaan atau interaksi yang sedang dialami. Emosi dapat berbentuk rasa senang, takut, marah, dan sebagainya.

Karaketristik emosi pada anak berbeda dengan karakteristik yang terjadi pada orang dewasa, dimana karekteristik emosi pada anak itu antara lain; (1) Berlangsung singkat dan berakhir tiba-tiba; (2) Terlihat lebih hebat atau kuat; (3) 
Bersifat sementara atau dangkal; (4) Lebih sering terjadi; (5) Dapat diketahui dengan jelas dari tingkah lakunya, dan (6) Reaksi mencerminkan individualitas (Nurmalitasari, 2015).

Berdasarkan penjelasan perkembangan sosial dan emosional diatas maka dapat diketahui bahwa perkembangan sosial emosional adalah dua hal yang saling mempengaruhi. Perkembangan emosi dominan mendorong aktivitas sosial seseorang. Kompetensi sosial ditentukan oleh kompetensi emosi seseorang. Seseorang dengan kecerdasan emosional yang tinggi cenderung menjadi pribadi yang kompeten secara sosial. Hal ini senada dengan pendapat Goleman (2015: 306) yang menyatakan bahwa kematangan emosi seorang anak merupakan kunci keberhasilan dalam menjalin hubungan sosialnya.

Sosial emosional anak merupakan suatu proses belajar anak tentang bagaimana berinteraksi dengan orang lain sesuai dengan aturan sosial yang ada, dan anak lebih mampu mengendalikan perasaan-perasaannya sesuai dengan kemampuan mengidentifikasi dan mengungkapkan perasaan tersebut (Ramli, 2005: 208). Rosmala Dewi (2005: 18), menyatakan bahwa sosial emosional merupakan kemampuan mengadakan hubungan dengan orang lain, terbiasa untuk bersikap sopan santun, mematuhi peraturan dan disiplin dalam kehidupan seharihari dan dapat menunjukkan reaksi emosi yang wajar.

Setiap aspek perkembangan individu, baik sosial maupun emosi, satu sama lainnya saling mempengaruhi. Adapun aspek perkembangan sosial yakni meliputi: (1) Interpersonal, yakni mampu bermain bersama teman, dapat bergantian dan antri, bisa memberikan dan menerima. (2) Personal, yakni mau merespon dan menjawab pertanyaan, mau mengekspresikan diri di kelas, mau bertanya, mau di tinggal selama di sekolah, dapat makan sendiri, memakai baju sendiri. Sedangkan aspek perkembangan emosional, yakni meliputi: (1) Rasa sayang kepada teman, orang tua, saudara dan guru. (2) Memiliki rasa empati, menolong teman. (3) Dapat mengontrol emosi, kemarahan, dan lainnya (Isjoni, 2013: 113).

Dewi (2015) mengatakan bahwa kemampuan sosial emosional anak adalah kemampuan untuk menjalin relasi dengan orang lain, terbiasa untuk sopan santun, 
mematuhi dan menjalankan peraturan serta disiplin dalam kehidupan sehari-hari dan dapat menunjukkan reaksi emosi yang wajar, perkembangan kemampuan sosial emosional meliputi perkembangan dalam hal emosi, kepribadian, dan hubungan interpersonal.

Goleman (2015: 307), juga menyebutkan bahwa salah satu kunci kecakapan sosial adalah seberapa baik atau buruk seseorang mengungkapkan perasaanya sehingga dapat diketahui bahwa perkembangan emosi sangat berpengaruh besar terhadap perkembangan sosial anak. Interaksi sosial membutuhkan keterampilan khusus yang didorong oleh kondisi emosi anak seperti motivasi, empati dan menyelesaikan konflik. Anak yang dapat mengendalikan diri dan mudah menunjukkan empati dan kasih sayang akan mudah bersosialisasi dengan orang disekitarnya (Pujiati, 2013).

\section{Siswa Broken Home}

Broken home secara etimologis berarti retak (Echols \& Shadily, 2003: 80), jadi broken home adalah kondisi keuarga yang tidak harmonis atau sudah tidak rukun dengan banyaknya pertengkaran dan dapat berakhir dengan penceraian. Yang dimaksud kasus keluarga pecah (broken home) dapat dilihat dari dua aspek: (1) keluarga itu terpecah karena strukturnya tidak untuk sebab salah satu kepala keluarga itu meninggal dunia atau telah bercerai; (2) orangtua yang tidak meninggal atau tidak bercerai tetapi salah satu ayah atau ibu sering tidak di rumah dan ada hubungan kasih sayang lagi (Willis, 2013: 66). Contohnya sering bertengkar, berselingkuh dan lain sebagainya sehingga keluarga tidak sehat lagi secara psikologi.

Kata Broken home menurut Helmawati (2014: 16), yaitu suatu kondisi keluarga yang mengalami perpecahan baik secara fisik maupun psikologis. Suatu keluarga terdiri dari ayah, ibu, dan anak yang terikat dalam sebuah perkawinan. Suatu perkawinan mengalami perpecahan fisik maupun psikologis, perpisahan secara fisik bisa terjadi jika salah satu dari kedua orang tua meninggal, maupun karena perceraian. Istilah "broken home" biasanya digunakan untuk menggambarkan keluarga yang berantakan akibat orang tua tidak lagi peduli 
dengan situasi dan keadaan keluarga di rumah. Orang tua tidak lagi perhatian terhadap anak-anaknya, baik masalah di rumah, sekolah, sampai pada perkembangan pergaulan anak-anaknya di masyarakat. Namun, broken home dapat juga diartikan dengan kondisi keluarga yang tidak harmonis dan tidak berjalan layaknya keluarga yang rukun, damai, dan sejahtera karena sering terjadi keributan serta perselisihan yang menyebabkan pertengkaran dan berakhir pada perceraian. Kondisi ini menimbulkan dampak yang sangat besar terutama bagi anak-anak. Bisa saja anak jadi murung, sedih yang berkepanjangan, dan malu. Selain itu, anak juga kehilangan pegangan serta panutan dalam masa transisi menuju kedewasaan.

Broken home dapat dikatakan sebagai kekacauan dalam sebuah keluarga. Kekacauan dalam keluarga merupakan bahan pengujian umum karena semua orang mungkin saja terkena salah satu dari berbagai jenisnya, dan karena pengalaman itu biasanya dramatis, menyangkut pilihan moral dan penyesuaianpenyesuaian pribadi yang dramatis. Kekacauan keluarga dapat ditafsirkan sebagai pecahnya suatu unit keluarga, terputusnya atau retaknya struktur peran sosial jika satu atau beberapa anggota gagal menjalankan kewajiban peran mereka secukupnya (Goode, 2007: 184). Pendapat lain mengenai pengertian broken home yaitu menurut Chaplin (2017: 71), mengungkapkan bahwa broken home adalah "keluarga atau rumah tangga tanpa hadirnya salah seorang dari kedua orang tua (ayah dan ibu) disebabkan oleh meninggal, perceraian, meninggalkan keluarga dan lain-lain". Kondisi keluarga yang kurang memberikan peran dalam kehidupan remaja sebagaimana mestinya ini berakibat kurang baik pula bagi pertumbuhan dan perkembangannya. Sedangkan menurut Pujosuwarno (1994: 7), broken home adalah "keretakan di dalam keluarga yang berarti rusaknya hubungan satu dengan yang lain di antara anggota keluarga tersebut". Dari keluarga yang te lah dijabarkan di atas akan dilahirkan sebagai anak yang rendah dalam berkepribadian, sehingga sikapnya sering melakukan kesalahan. Mereka mengalami gangguan emosional yang merugikan diri sendiri bahkan orang lain. Kasus keluarga broken home banyak ditemukan di sekolah-sekolah SD, SMP, SMA bahkan di perguruan tinggi 
negri maupun swasta, dengan penyesuaian diri yang kurang baik seperti membolos saat pelajaran, berbohong, brutal dan menantang gurunya sendiri.

Memang semua broken home tidak sesuai dengan apa yang sudah dijelaskan di atas, terutama dalam kasus meninggal dunia atau bercerai. Karena masih ada sanak sodara paman atau bibi yang masih bisa mengurus anak-anak itu, maka kasus anak-anak nakal tidak akan terjadi. Pastinya ada bimbingan khusus untuk mengatasi broken home seperti diberikan pendidikan agama, pendidikan umum dan berakhlak mulia.

Selaras dengan hal itu Willis (2013: 66), mengemukakan bahwa: Dari keluarga Broken Home akan lahir anak-anak yang mengalami krisis kepribadian, sehingga perilakunya salahsuai. Mereka mengalami gangguan emosional dan bahkan neurotik. Kasus keluarga Broken Home ini sering ditemui disekolah dengan penyesuaian diri yang kurang baik, seperti malas belajar, menyendiri, agresif, membolos, dan suka menentang guru. Berdasarkan pandangan Willis di atas dapat disimpulkan bahwa anak yang terlahir dari keluarga Broken Home kebanyakan mengalami gangguan emosional yang berpengaruh kepada cara mereka berperilaku. Perilaku mereka cenderung menyimpang atau tidak sesuai. Perilaku anak tersebut nampak ketika mereka berada dilingkungan sekolah maupun dilingkungan masyarakat.

Menurut Willis, (2013: 66), broken home dapat dilihat dari dua aspek yaitu: (1) Keluarga itu terpecah karena strukturnya tidak utuh sebab salah satu darikepala keluarga itu meninggal atau telah bercerai, (2) Orang tua tidak bercerai akan tetapi struktur keluarga itu tidak utuh lagi karena ayah atau ibu sering tidak dirumah,dan atau tidak memperlihatkan hubungan kasih sayang lagi. Misalnya orang tua sering bertengkar sehingga keluarga itu tidak sehat secara psikologis. Dari keluarga yang digambarkan diatas, akan lahir anak-anak yang mengalami krisis kepribadian, sehingga perilakunya sering salah. Mereka mengalami gangguan emosional dan bahkan neurotic.

Dapat disimpulkan bahwa keluarga broken home yaitu keluarga yang tidak harmonis. Dimana di dalam sebuah keluarga orang tua yang sibuk dengan 
pekerjaannya sehingga anak merasa kurang mendapatkan perhatian, juga kurang adanya komunikasi antara anggota keluarga satu dengan keluarga lainnya, sehingga keadaan tersebut membuat keluarga menjadi tidak hangat.

Banyak faktor yang menyebabkan terjadinya pertikaian dalam keluarga yang berakhir dengan perceraian. Faktor-faktor ini antara lain: persoaalan ekonomi, perbedaan usia yang besar, keinginan memperoleh anak putra (putri) dan persoalan prinsip hidup yang berbeda. Faktor lainnya merupakan berupa perbedaan penkanan dan cara mendidik anak, juga dukungan sosial dari pihak luar, tetangga, sanak saudara, sahabat, dan situasi masyarakat yang keruh dan meruntuhkan kehidupan rumah tangga (Dagun, 2013: 114).

Adapun faktor-faktor yang menyebabkan broken home adalah:

a. Terjadinya Perceraian

Faktor yang menjadi penyebab perceraian adalah pertama adanya disorientasi tujuan suami istri dalam membangun mahligai rumah tangga; dan faktor kedewasaan yang mencakup intelektualitas, emosionalitas, kedua, kemampuan mengelola dan mengatasi berbagai masalah keluarga: ketiga, pengaruh perubahan dan norma yang berkembang di masyarakat.

b. Ketidakdewasaan Sikap Orang Tua

Ketidakdewasaan sikap orang tua salah satunya dilihat dari sikap egoisme dan egosentrisme. Egoisme adalah suatu sifat buruk manusia yang mementingkan dirinya sendiri. Sedangkan egosentrisme adalah sikap yang menjadikan dirinya pusat perhatian yang diusahakan oleh seseorang dengan segala cara. Egoisme orang tua akan berdampak kepada anaknya, yaitu timbul sifat membandel, sulit di suruh dan suka bertengkar dengan saudaranya. Adapun sikap membandel adalah aplikasi dari rasa marah terhadap orang tua yang egosentrisme. Seharusnya orang tua memberi contoh yang baik seperti suka bekerjasama, saling membantu, bersahabat dan ramah. Sifat-sifat ini adalah lawan dari egoisme dan egosentrisme.

c. Orang Tua yang Kurang Memiliki Rasa Tanggungjawab 
Tidak bertanggungjawabnya orang tua salah satunya masalah kesibukan. Kesibukan adalah satu kata yang telah melekat pada masyarakat modern di kota-kota. Kesibukannya terfokus pada pencarian materi yaitu harta dan uang. Mengapa demikian? Karena filsafat hidup mereka mengatakan uang adalah harga diri, dan waktu adalah uang. Jika telah kaya berarti suatu keberhasilan, suatu kesuksesan. Di samping itu kesuksesan lain adalah jabatan tinggi.

d. Jauh dari Tuhan

Segala sesuatu perilaku manusia disebabkan karena dia jauh dari Tuhan. Sebab, Tuhan mengajarkan agar manusia berbuat baik. Jika keluarga jauh dari Tuhan dan mengutamakan materi dunia semata maka kehancuran dalam keluarga itu akan terjadi. Karena dari keluarga tersebut akan lahir anak-anak yang tidak taat kepada Tuhan dan kedua orang tuanya

e. Adanya Masalah Ekonomi

Dalam suatu keluarga mengalami kesulitan dalam memenuhi kebutuhan rumah tangga. Istri banyak menuntut hal-hal diluar makan dan minum. Padahal dengan penghasilan suami sebagai buruh lepas, hanya dapat memberikan makan dan rumah petak tempat berlindung yang sewanya terjangkau. Karena suami tidak sanggup memenuhi tuntutan istri dan anakanaknya akan kebutuhan-kebutuhan yang disebutkan tadi, maka timbulah pertengkaran suami-istri yang sering menjurus ke arah perceraian.

f. Kehilangan Kehangatan

Di dalam Keluarga Antara orang tua dan anak kurang atau putus komunikasi diantara anggota keluarga menyebabkan hilangnya kehangatan di dalam keluarga antara orang tua dan anak. Faktor kesibukan biasanya sering dianggap penyebab utama dari kurangnya komunikasi. Dimana ayah dan ibu bekerja dari pagi hingga sore hari, mereka tidak punya waktu untuk makan siang bersama, shalat berjamaah di rumah dimana ayah menjadi imam, sedang anggota yang lain menjadi jamaah. Dan anak-anak akan mengungkapkan pengalaman perasaan dan pemikiran-pemikiran tentang kebaikan keluarga termasuk kritik terhadap orang tua mereka. Sering terjadi adalah kedua orang 
tua pulang hampir malam karena jalanan macet, badan capek, sampai di rumah mata mengantuk dan tertidur. Tentu orang tidak mempunyai kesempatan untuk berdiskusi dengan anak-anaknya.

g. Adanya Masalah Pendidikan

Masalah pendidikan sering menjadi penyebab terjadinya broken home. Jika pendidikan agak lumayan pada suami istri maka wawasan tentang kehidupan keluarga dapat dipahami oleh mereka. Sebaliknya pada suami istri yang pendidikannya rendah sering tidak dapat memahami lika-liku keluarga. Karena itu sering salah menyalahkan bila terjadi persoalan di keluarga. Akibatnya selalu terjadi pertengkaran yang mungkin akan menimbulkan perceraian. Jika pendidikan agama ada atau lumayan mungkin sekali kelemahan dibanding pendidikan akan di atasi. Artinya suami istri akan dapat mengekang nafsu masingmasing sehingga pertengkaran dapat dihindari (Dagun, 2013: 115-116).

\section{Perkembangan Sosial-emosional Siswa Broken Home Kelas II Mi Roudlotus Saidiyyah Semarang}

Siswa Usia Dasar (6-12 tahun) memiliki tugas perkembangan yang berkaitan dengan keterampilan sosial emosional. Pada saat anak memasuki Sekolah Dasar, ia akan lebih banyak menghabiskan waktu disekolah yaitu dengan guru dan teman-temannya (Nuryanto, 2005). Perkembangan sosialemosional individu siswa ditandai dengan interaksi sosioal yang baik, mudah bergaul dengan orang lain maupun teman sebaya, beradaptasi dengan lingkungan dan mampu menempatkan posisi perkembangan emosional secara baik (Latifa, 2017).

Perkembangan sosial-emosional pada siswa Usia Dasar merupakan perkembangan perilaku dalam mengendalikan dan menyesuaikan diri dengan aturan-aturan masyarakat sosial dimana anak tersebut berada. Hasil penelitian yang telah dilakukan pada tanggal 27 April 2021 dengan cara wawancara dan observasi pada objek penelitian, yakni siswa kelas II MI Roudlotus Saidiyyah 
Semarang yang bernama Mutiara Ramadhani (MR) yang merupakan salah satu anak Broken home, diperoleh hasil sebagai berikut.

Peneliti mendapatkan informasi dari guru kelas objek bahwa orang tua MR pisah (bercerai) sejak MR berusia 3 Tahun yang disebabkan masalah perekonomian. Atas perceraian tersebut, hak asuh MR jatuh ditangan Ayahnya. Anak yang seharusnya mendapat kasih sayang dari seorang Ibu, kini hanya didapat dari sosok Ayah yang harus membagi waktunya untuk tetap mencari nafkah dalam menghidupi keluarganya. Melihat demikian, Bude (kakak dari Ayah MR) turut membatu mengasuh MR bersama anak-anaknya.

Sejak perceraian itu MR pertama kali bertemu Ibunya pada usia 7 Tahun dan melihat Ibunya sudah bersuami. Ibu MR memlih bercerai dengan Ayah MR kemudian merantau di Ibu Kota Jakarta untuk mencari kerja. Pada pertemuan tersebut, Ibu MR meminta agar MR di taruh di Pondok Pesantren yang ada di Kota semarang, yakni Roudlotus Saidiyyah. Atas pertimbangan dari berbagai pihak akhirnya di setujui.

Perhatian dan kasih sayang yang seharusnya diberikan orang tua, kini ditanggung oleh lingkungan MR. Dalam mendidik MR, guru MR menyampaikan bahwa MR memiliki perkembangan sosial-emosional yang sama dengan teman sebayanya, bahkan dia terlihat lebih dewasa. Analisis perkembangan sosial emosional diteliti melalui dua tempat yakni didalam kelas dan diluar kelas.

a. Analisis perkembangan Sosial-emosional didalam kelas

Perkembangan sosial emosional adalah perubahan kepribadian anak. Hal ini disebabkan bahwa dunia anak dipenuhi dengan pengalaman emosional. Pengalaman ini diperoleh setelah adanya perubahan karena hubungan dengan orang lain atau setelah terjadinya interaksi.

Berdasarkan hasil penelitian di MI Roudlotus Saidiyyah Semarang, diperoleh hasil analisis perkembangan sosial-emosional pada anak Broken home, yakni siswa tersebut mampu beriteraksi dan berkomunikasi dengan baik, hal ini dibuktikan adanya feedback saat berkomunikasi antara guru dan siswa saat kegiatan belajar mengajar dan siswa tersebut mempunyai 
rasa percaya tinggi dan rasa ingin tau yang tinggi yakni siswa tersebut bertanya secara langsung kepada guru tentang materi yang belum mereka pahami.

'Perkembangan sosial-emosional merupakan perkembangan yang melibatkan hubungan maupun interaksi dengan orang lain melalui perasaan yang diungkapkan seseorang terhadap orang lain dan mampu mengembangkan perilaku sosial dan mengendalikan dalam hal emosi (Wardany, 2017).

Berdasarkan hasil penelitian di MI Roudlotus Saidiyyah Semarang salah satu siswa kelas II yang merupakan korban Broken home, mampu mengendalikan perilaku sosial dan pengendalian emosi hal ini terlihat ketika siswa tersebut mampu menyesuaikan emosi kepada temannya yakni menunjukkan sikap saling kasih sayang, berpartisipasi dalam kegiatan kerjasama, dan ikut serta dalam menyelesaikan masalah di dalam kelas.

Dapat ditarik kesimpulan bahwa kemampuan MR dalam berinteraksi atau berkomunikas baik dengan guru maupun teman sebaya, menunjukkan komunikasi dengan baik dan sopan, baik dengan guru maupun dengan temannya. MR juga menunjukkan sikap toleransi dan kasih sayang kepada teman sebaya saat dikelas, ditunjukkan dengan adanya interaksi dan komunikasi yang baik saat berkomunikasi dan bekerja sama yang membahas mengenai materi pembelajaran, anak menunjukkan feedback yang tepat dengan teman sebaya ketika ada teman yang bertanya kepadanya, MR mampu menempatkan sikap emosionalnya berdasarkan tempatnya, MR dapat bekerja sama dengan baik ketika ada pembelajaran yang bersifat kelompok dan dapat menyelesaikan permasalahan yang baik terhadap sesama teman sebayanya, siswa tersebut mampu menyelesaikan masalah dengan cara bermusyawarah terhadap sesama teman untuk menemukan solusi demi untuk mencapai tujuan bersama.

b. Analisis perkembangan Sosial-emosional di luar kelas 
Berdasarkan hasil analisis penelitian perkembangan sosial-emosional di MI Roudlotus Saidiyyah Semarang salah satu siswa kelas II yang merupakan korban Broken home menunjukkan sosial-emosional yang baik yakni mudah bergaul saat bermain, dan mudah beriteraksi dengan sesaman teman saat bermain bersama, mengajak teman lain untuk ikut serta dalam permainan, membantu teman lain saat membutuhkan pertolongan saat bermain, dan mampu menyelesaikan permasalahan dengan kelompok bermain dan mampu memelihara kelompok bermain agar tidak terjadi perselisihan, dan mengayomi teman lain saat bermain. Perkembangan sosial-emosional yang positif memudahkan anak untuk bergaul dengan sesamanya dan belajar dengan lebih baik, juga dalam aktivitas lingkungan sosial (Nurjanah, 2017).

Perkembangan sosial emosional adalah perkembangan perilaku dalam pengendalian dan peneyesuaian diri dengan aturan masyarakat. Perkembangan sosial-emosional sangat dipengaruhi oleh lingkungan sosial emosional yakni orang tua, guru dan teman sebaya (Suryati, 2016). Berdasarkan hasil analisis menunjukkan bahwa sosial- emosional anak yang mengalami broken home di MI Roudlotus Saidiyyah Semarang tergolong baik. MR menunjukkan partisipasi yang baik dan mendorong teman yang lain untuk ikut bersama, membatu teman lain saat membutuhkan pertolongan, memberikan respon feedback ketika diajak teman lain bermain bersama dengan ekspresi bahagia dan gembira, menyapa teman dengan baik saat berinteraksi bermain, berpartisipasi dengan baik dalam sebuah permainan yang bertujuan untuk menciptakan permainan yang sempurna, selain itu MR tidak marah ketika diajak bercanda oleh temannya. Marah merupakan hal yang sangat umum terjadi pada seorang anak, tingkat emosi mereka yang masih labil menjadi salah satu hal yang diperhatikan oleh tenaga pendidik.

Berdasarkan hasil wawancara dapat ditarik kesimpulan bahwa kemampuan anak ketika bergabung bersama teman saat bermain 
yakni bisa menyesuaikan individu dengan kelompok bermain, MR mempunyai inisiatif tersendiri ketika bermain yakni mampu mengayomi teman-temannya saat bermain dan menunjukkan sikap saling menyayangi, siswa tersebut dapat memelihara peran bermain saat bermain dengan teman sebaya dengan cara lebih menekankan nilai kebersamaan terhadap sesama teman bermain, MR merasa senang ketika berinteraksi dengan teman sebaya, siswa tersebut mempunyai rasa perduli yang tinggi terhadap teman (menolong teman yang sedang kesusahan).

Menurut Siti Cholifah, yaitu wali kelas II menerangkan bahwa menciptakan suasana yang akrab adalah dengan sesering mungkin guru berinteraksi dengan siswa, hal ini akan berdampak kepada tingkat emosional siswa yang stabil karena ada sosok lebih dewasa yang dapat menjadi contoh mereka dan tempat mereka mencurahkan masalah.

\section{Simpulan}

Pada saat anak memasuki usia sekolah dasar (6-12 Tahun) memiliki tugas perkembangan yang berkaitan dengan ketrampilan sosial-emosional. Perkembangan sosial-emosional pada siswa Usia Dasar merupakan perkembangan perilaku dalam mengendalikan dan menyesuaikan diri dengan aturan-aturan masyarakat sosial dimana anak tersebut berada. Analisis perkembangan sosial emosional yang kami teliti melalui dua tempat yakni diluar kelas dan didalam kelas. Pertama, perkembangan sosial-emosional pada anak Broken home didalam kelas, yakni siswa tersebut (1) Mampu beriteraksi dan berkomunikasi dengan baik, hal ini dibuktikan adanya feedback saat berkomunikasi antara guru dan siswa saat kegiatan belajar mengajar dan siswa tersebut mempunyai rasa percaya tinggi dan rasa ingin tau yang tinggi yakni siswa tersebut bertanya secara langsung kepada guru tentang materi yang belum mereka pahami. (2) Mampu mengendalikan perilaku sosial dan pengendalian emosi hal ini terlihat ketika siswa tersebut 
mampu menyesuaikan emosi kepada temannya yakni menunjukkan sikap saling kasih sayang, berpartisipasi dalam kegiatan kerjasama, dan ikut serta dalam menyelesaikan masalah di dalam kelas.

Kedua, perkembangan sosial-emosional pada anak Broken home diluar kelas, yakni siswa tersebut (1) Mudah bergaul saat bermain, dan mudah beriteraksi dengan sesama teman saat bermain bersama, mengajak teman lain untuk ikut serta dalam permainan, membantu teman lain saat membutuhkan pertolongan saat bermain, dan mampu menyelesaikan permasalahan dengan kelompok bermain dan mampu memelihara kelompok bermain agar tidak terjadi perselisihan, dan mengayomi teman lain saat bermain. (2) Mudah berinteraksi dan mudah bergaul dengan teman sebaya karena guru atau wali kelas ii selalu memberikan stimulus atau dukungan anak tersebut saat berhubungan dengan orang lain maupun teman sebaya.

Siswa Broken home dalam perkembangan sosial-emosionalnya membutuhkan bantuan dan program yang sesuai dengan kebutuhan dan usianya. Karena siswa tersebut berada dalam lingkungan Guru, maka guru selalu memberi bimbingan dan arahan, guru memberi dorongan untuk mencapai perkembangan sosial-emosional anak Broken home agar sama dengan teman yang lainnya. 


\section{DAFTAR PUSTAKA}

Chaplin, J. P. (2017). Kamus Lengkap Psikologi. Jakarta: Raja Grafindo Persada. Dagun, S. . (2013). Psikologi Keluarga. Jakarta: Rineka Cipta.

Dewi, R. (2005). Berbagai Masalah Anak Taman Kanak-kanak. Jakarta: Depdiknas Dirjen Dikti.

Dewi, S. (2015). Pengaruh Kecerdasan Emosional dan Spritual Terhadap. Kinerja: Studi Kasus Pada Perawat di RSAB Harapan Kita. STIE IPWIJA.

Echols, J. M., \& Shadily, H. (2003). Kamus Indonesia-Inggris. Jakarta: Gramedia Pustaka Utama.

Goleman, D. (2015). Emotional Intelligence. Jakarta: Gramedia Pustaka Utama.

Goode, W. J. (2007). Sosiologi Keluarga. Jakarta: Bumi Aksara.

Helmawati. (2014). Pendidikan Keluarga. Bandung: Remaja Rosadakarya.

Hurlock, E. B. (2004). Psikologi Perkembangan: Suatu Pendekatan Rentang Kehidupan. Jakarta: Erlangga.

Isjoni. (2013). Pembelajaran Kooperatif Meningkatkan Kecerdasan Komunikasi Antar Peserta Didik. Yogyakarta: Pustaka Pelajar.

Latifah, U. (2017). Aspek Perkembangan Pada Anak Sekolah Dasar Masalah dan Perkembangan Jurnal of Multidisciplinary Studies. Vol.1. No.2

Latipah, L. F. (2017). Perkembangan Kemampuan Kgnitif dan Sosial Empsional Melalui Penerapan Media Balok dan Bermain Peran Pada Siswa TK Kuntum Mekar Lampung. Al-Athfal:Jurnal Pendidikan Anak. Vol.3. No.2

Loree, M. R. (1970). Psychology of Education. New York: The Ronald Press.

Makmun, A. S. (1996). Psikologi Pendidikan Perangkat Sistem Pengajaran Modul. Bandung: Remaja Rosadakarya.

Nurjanah. (2017). Mengembangkan Kecerdasan Sosial Emosional Anak Usia Dini Melalui Keteladanan. Jurnal Bimbingan Konseling dan Dakwah Islam. Vol.14. No.1

Nurmalitasari, F. (2015). Perkembangan Sosial Emosi pada Anak Usia Prasekolah. Buletin Psikologi, 23(2), 103-111.

Nuryanto, R. R. 2005. Efektivitas Pelatihan untuk Meningkatkan Keterampilan Sosial Pada Anak Sekolah Dasar Kelas 5. Jurnal Berkala Ilmiah Psikologi. Vo,7. No.1

Pujiati, D. (2013). Peningkatan Keterampilan Sosial Melalui Metode Bermain Peran. JURNAL PENDIDIKAN USIA DINI, 7(2).

Pujosuwarno, S. (1994). Bimbingan dan Konseling Keluarga. Yogyakarta: Menara Mas Ofset.

Rachmawati, Y. E. (2013). Hubungan antara Self Efficacy dengan Kematangan Karir pada Mahasiswa Tingkat Awal dan Tingkat Akhir di Universitas Surabaya. Calyptra: Ilmiah Mahasiswa Universitas Surabaya, 1 (1).

Ramli, M. (2005). Pendampingan Perkembangan Anak Usia Dini. Jakarta: Departemen Pendidikan Nasional, Direktorat Jenderal Pendidikan.

Sugiyono. (2013). Metode Penelitian Pendidikan Pendekatan Kuantitatif, Kualitatif, dan R\&D. Bandung: Alfabeta.

Suryati, E. (2016). Upaya Meningkatkan Perkembangan Sosial-Emosional Melalui 
Kegiatan Permainan Tradisional Ular Naga Pada Anak Kelompok B. Jurnal Pendidikan Anak Usia Dini Universitas Pendidikan Ganesha. Vol.4. No.1

Susanto, A. (2013). Teori Belajar dan Pembelajaran di Seklah Dasar. Jakarta: Kencana Prenada Media Group.

Wardany, M. P. (2017). Aktivitas Bermain Kooperatif Meningkatkan Perkembangan Sosial-Emosional Anak

Willis, S. S. (2013). Konseling Keluarga. Bandung: Alfabeta.

Zusnani, I.( 2013). Pendidikan Kepribadian Siswa SD-SMP. Yogyakarta: Platinum 